HANDBOOK OF PHILOSOPHICAL LOGIC 2ND EDITION

VOLUME 12 


\title{
HANDBOOK \\ OF PHILOSOPHICAL LOGIC
}

\author{
2nd Edition
}

Volume 12

edited by D.M. Gabbay and F. Guenthner

Volume 1 - ISBN 0-7923-7018-X

Volume 2 - ISBN 0-7923-7126-7

Volume 3 - ISBN 0-7923-7160-7

Volume 4 - ISBN 1-4020-0139-8

Volume 5 - ISBN 1-4020-0235-1

Volume 6 - ISBN 1-4020-0583-0

Volume 7 - ISBN 1-4020-0599-7

Volume 8 - ISBN 1-4020-0665-9

Volume 9 - ISBN 1-4020-0699-3

Volume 10 - ISBN 1-4020-1644-1

Volume 11 - ISBN 1-4020-1966-1 


\title{
HANDBOOK OF PHILOSOPHICAL LOGIC
}

\section{2nd EDITION \\ VOLUME 12}

\author{
Edited by \\ D.M. GABBAY \\ King's College, London, U.K. \\ and \\ F. GUENTHNER
}

Centrum für Informations- und Sprachverarbeitung,

Ludwig-Maximilians-Universität München, Germany 
A C.I.P. Catalogue record for this book is available from the Library of Congress.

ISBN-10 1-4020-3091-6 (HB)

ISBN-13 978-1-4020-3091-8 (HB)

ISBN-10 1-4020-3092-4 (e-book)

ISBN-13 978-1-4020-3092-5 (e-book)

Published by Springer,

P.O. Box 17, 3300 AA Dordrecht, The Netherlands.

www.springeronline.com

Printed on acid-free paper

All Rights Reserved

(C) 2005 Springer

No part of this work may be reproduced, stored in a retrieval system, or transmitted in any form or by any means, electronic, mechanical, photocopying, microfilming, recording or otherwise, without written permission from the Publisher, with the exception of any material supplied specifically for the purpose of being entered and executed on a computer system, for exclusive use by the purchaser of the work.

Printed in the Netherlands. 


\section{CONTENTS}

Preface to the Second Edition vii

Dov M. Gabbay

Knowledge Representation with Logic Programs 1

Gerhard Brewka and Jürgen Dix

The Resolution Principle $\quad 87$

Alexander Leitsch and Christian Fermüller

How to Go Nonmonotonic

175

David Makinson

Development of Categorical Logic

279

John Bell

Index

363 


\section{PREFACE TO THE SECOND EDITION}

It is with great pleasure that we are presenting to the community the second edition of this extraordinary handbook. It has been over 15 years since the publication of the first edition and there have been great changes in the landscape of philosophical logic since then.

The first edition has proved invaluable to generations of students and researchers in formal philosophy and language, as well as to consumers of logic in many applied areas. The main logic article in the Encyclopaedia Britannica 1999 has described the first edition as 'the best starting point for exploring any of the topics in logic'. We are confident that the second edition will prove to be just as good!

The first edition was the second handbook published for the logic community. It followed the North Holland one volume Handbook of Mathematical Logic, published in 1977, edited by the late Jon Barwise. The four volume Handbook of Philosophical Logic, published 1983-1989 came at a fortunate temporal junction at the evolution of logic. This was the time when logic was gaining ground in computer science and artificial intelligence circles.

These areas were under increasing commercial pressure to provide devices which help and/or replace the human in his daily activity. This pressure required the use of logic in the modelling of human activity and organisation on the one hand and to provide the theoretical basis for the computer program constructs on the other. The result was that the Handbook of Philosophical Logic, which covered most of the areas needed from logic for these active communities, became their bible.

The increased demand for philosophical logic from computer science and artificial intelligence and computational linguistics accelerated the development of the subject directly and indirectly. It directly pushed research forward, stimulated by the needs of applications. New logic areas became established and old areas were enriched and expanded. At the same time, it socially provided employment for generations of logicians residing in computer science, linguistics and electrical engineering departments which of course helped keep the logic community thriving. In addition to that, it so happens (perhaps not by accident) that many of the Handbook contributors became active in these application areas and took their place as time passed on, among the most famous leading figures of applied philosophical logic of our times. Today we have a handbook with a most extraordinary collection of famous people as authors!

The table below will give our readers an idea of the landscape of logic and its relation to computer science and formal language and artificial intelligence. It shows that the first edition is very close to the mark of what was needed. Two topics were not included in the first edition, even though

D. Gabbay and F. Guenthner (eds.),

Handbook of Philosophical Logic, Volume 12, vii-xiii.

(C) 2005, Springer. Printed in the Netherlands. 
they were extensively discussed by all authors in a 3-day Handbook meeting. These are:

- a chapter on non-monotonic logic

- a chapter on combinatory logic and $\lambda$-calculus

We felt at the time (1979) that non-monotonic logic was not ready for a chapter yet and that combinatory logic and $\lambda$-calculus was too far removed. ${ }^{1}$ Non-monotonic logic is now a very major area of philosophical logic, alongside default logics, labelled deductive systems, fibring logics, multi-dimensional, multimodal and substructural logics. Intensive reexaminations of fragments of classical logic have produced fresh insights, including at time decision procedures and equivalence with non-classical systems.

Perhaps the most impressive achievement of philosophical logic as arising in the past decade has been the effective negotiation of research partnerships with fallacy theory, informal logic and argumentation theory, attested to by the Amsterdam Conference in Logic and Argumentation in 1995, and the two Bonn Conferences in Practical Reasoning in 1996 and 1997.

These subjects are becoming more and more useful in agent theory and intelligent and reactive databases.

Finally, fifteen years after the start of the Handbook project, I would like to take this opportunity to put forward my current views about logic in computer science, computational linguistics and artificial intelligence. In the early 1980s the perception of the role of logic in computer science was that of a specification and reasoning tool and that of a basis for possibly neat computer languages. The computer scientist was manipulating data structures and the use of logic was one of his options.

My own view at the time was that there was an opportunity for logic to play a key role in computer science and to exchange benefits with this rich and important application area and thus enhance its own evolution. The relationship between logic and computer science was perceived as very much like the relationship of applied mathematics to physics and engineering. Applied mathematics evolves through its use as an essential tool, and so we hoped for logic. Today my view has changed. As computer science and artificial intelligence deal more and more with distributed and interactive systems, processes, concurrency, agents, causes, transitions, communication and control (to name a few), the researcher in this area is having more and more in common with the traditional philosopher who has been analysing

\footnotetext{
${ }^{1} \mathrm{I}$ am really sorry, in hindsight, about the omission of the non-monotonic logic chapter. I wonder how the subject would have developed, if the AI research community had had a theoretical model, in the form of a chapter, to look at. Perhaps the area would have developed in a more streamlined way!
} 
such questions for centuries (unrestricted by the capabilities of any hardware).

The principles governing the interaction of several processes, for example, are abstract an similar to principles governing the cooperation of two large organisation. A detailed rule based effective but rigid bureaucracy is very much similar to a complex computer program handling and manipulating data. My guess is that the principles underlying one are very much the same as those underlying the other.

I believe the day is not far away in the future when the computer scientist will wake up one morning with the realisation that he is actually a kind of formal philosopher!

The projected number of volumes for this Handbook is about 18. The subject has evolved and its areas have become interrelated to such an extent that it no longer makes sense to dedicate volumes to topics. However, the volumes do follow some natural groupings of chapters.

I would like to thank our authors and readers for their contributions and their commitment in making this Handbook a success. Thanks also to our publication administrator Mrs J. Spurr for her usual dedication and excellence and to Kluwer Academic Publishers (now Springer) for their continuing support for the Handbook.

Dov Gabbay

King's College London 


\begin{tabular}{|c|c|c|c|c|}
\hline Logic & IT & & & \\
\hline & $\begin{array}{l}\text { Natural } \\
\text { language } \\
\text { processing }\end{array}$ & $\begin{array}{l}\text { Program } \\
\text { control spec- } \\
\text { ification, } \\
\text { verification, } \\
\text { concurrency }\end{array}$ & $\begin{array}{l}\text { Artificial in- } \\
\text { telligence }\end{array}$ & $\begin{array}{l}\text { Logic pro- } \\
\text { gramming }\end{array}$ \\
\hline $\begin{array}{l}\text { Temporal } \\
\text { logic }\end{array}$ & $\begin{array}{l}\text { Expressive } \\
\text { power of tense } \\
\text { operators. } \\
\text { Temporal } \\
\text { indices. Sepa- } \\
\text { ration of past } \\
\text { from future }\end{array}$ & \begin{tabular}{l}
\multicolumn{3}{l}{ Expressive } \\
power for re- \\
current events. \\
Specification \\
of tempo- \\
ral control. \\
Decision prob- \\
lems. Model \\
checking.
\end{tabular} & $\begin{array}{l}\text { Planning. } \\
\text { Time depen- } \\
\text { dent data. } \\
\text { Event calculus. } \\
\text { Persistence } \\
\text { through time- } \\
\text { the Frame } \\
\text { Problem. Tem- } \\
\text { poral query } \\
\text { language. } \\
\text { temporal } \\
\text { transactions. }\end{array}$ & $\begin{array}{l}\text { Extension of } \\
\text { Horn clause } \\
\text { with time } \\
\text { capability. } \\
\text { Event calculus. } \\
\text { Temporal logic } \\
\text { programming. }\end{array}$ \\
\hline $\begin{array}{l}\text { Modal logic. } \\
\text { Multi-modal } \\
\text { logics }\end{array}$ & $\begin{array}{l}\text { generalised } \\
\text { quantifiers }\end{array}$ & Action logic & $\begin{array}{l}\text { Belief revision. } \\
\text { Inferential } \\
\text { databases }\end{array}$ & $\begin{array}{lr}\text { Negation } & \text { by } \\
\text { failure } & \text { and } \\
\text { modality } & \end{array}$ \\
\hline $\begin{array}{l}\text { Algorithmic } \\
\text { proof }\end{array}$ & $\begin{array}{l}\text { Discourse rep- } \\
\text { resentation. } \\
\text { Direct com- } \\
\text { putation on } \\
\text { linguistic input }\end{array}$ & $\begin{array}{l}\text { New logics. } \\
\text { Generic theo- } \\
\text { rem provers }\end{array}$ & $\begin{array}{l}\text { General theory } \\
\text { of reasoning. } \\
\text { Non-monotonic } \\
\text { systems }\end{array}$ & $\begin{array}{l}\text { Procedural ap- } \\
\text { proach to logic }\end{array}$ \\
\hline $\begin{array}{l}\text { Non- } \\
\text { monotonic } \\
\text { reasoning }\end{array}$ & $\begin{array}{l}\text { Resolving } \\
\text { ambigui- } \\
\text { ties. Machine } \\
\text { translation. } \\
\text { Document } \\
\text { classification. } \\
\text { Relevance } \\
\text { theory }\end{array}$ & $\begin{array}{l}\text { Loop checking. } \\
\text { Non-monotonic } \\
\text { decisions about } \\
\text { loops. Faults } \\
\text { in systems. }\end{array}$ & $\begin{array}{l}\text { Intrinsic logical } \\
\text { discipline for } \\
\text { AI. Evolving } \\
\text { and com- } \\
\text { municating } \\
\text { databases }\end{array}$ & $\begin{array}{l}\text { Negation by } \\
\text { failure. Deduc- } \\
\text { tive databases }\end{array}$ \\
\hline $\begin{array}{l}\text { Probabilistic } \\
\text { and fuzzy } \\
\text { logic }\end{array}$ & $\begin{array}{l}\text { logical analysis } \\
\text { of language }\end{array}$ & $\begin{array}{l}\text { Real time sys- } \\
\text { tems }\end{array}$ & $\begin{array}{l}\text { Expert sys- } \\
\text { tems. Machine } \\
\text { learning }\end{array}$ & $\begin{array}{l}\text { Semantics for } \\
\text { logic programs }\end{array}$ \\
\hline $\begin{array}{l}\text { Intuitionistic } \\
\text { logic }\end{array}$ & $\begin{array}{l}\text { Quantifiers in } \\
\text { logic }\end{array}$ & $\begin{array}{l}\text { Constructive } \\
\text { reasoning and } \\
\text { proof theory } \\
\text { about specifi- } \\
\text { cation design }\end{array}$ & $\begin{array}{l}\text { Intuitionistic } \\
\text { logic is a better } \\
\text { logical basis } \\
\text { than classical } \\
\text { logic }\end{array}$ & $\begin{array}{l}\text { Horn clause } \\
\text { logic is really } \\
\text { intuitionistic. } \\
\text { Extension of } \\
\text { logic program- } \\
\text { ming languages }\end{array}$ \\
\hline $\begin{array}{l}\text { Set theory, } \\
\text { higher-order } \\
\text { logic, } \lambda \text { - } \\
\text { calculus, } \\
\text { types }\end{array}$ & $\begin{array}{l}\text { Montague } \\
\text { semantics. } \\
\text { Situation } \\
\text { semantics }\end{array}$ & $\begin{array}{l}\text { Non-well- } \\
\text { founded sets }\end{array}$ & $\begin{array}{l}\text { Hereditary fi- } \\
\text { nite predicates }\end{array}$ & $\begin{array}{l}\lambda \text {-calculus ex- } \\
\text { tension to logic } \\
\text { programs }\end{array}$ \\
\hline
\end{tabular}




\begin{tabular}{|c|c|c|c|c|}
\hline $\begin{array}{l}\text { Imperative } \\
\text { vs. declar- } \\
\text { ative lan- } \\
\text { guages }\end{array}$ & $\begin{array}{l}\text { Database } \\
\text { theory }\end{array}$ & $\begin{array}{l}\text { Complexity } \\
\text { theory }\end{array}$ & Agent theory & $\begin{array}{l}\text { Special com- } \\
\text { ments: } \\
\text { look to the } \\
\text { future }\end{array}$ \\
\hline $\begin{array}{l}\text { Temporal logic } \\
\text { as a declarative } \\
\text { programming } \\
\text { language. The } \\
\text { changing past } \\
\text { in databases. } \\
\text { The imperative } \\
\text { future }\end{array}$ & $\begin{array}{l}\text { Temporal } \\
\text { databases } \\
\text { and temporal } \\
\text { transactions }\end{array}$ & $\begin{array}{l}\text { Complexity } \\
\text { questions of } \\
\text { decision pro- } \\
\text { cedures of the } \\
\text { logics involved }\end{array}$ & $\begin{array}{l}\text { An essential } \\
\text { component }\end{array}$ & $\begin{array}{l}\text { Temporal } \\
\text { systems are } \\
\text { becoming more } \\
\text { and more so- } \\
\text { phisticated } \\
\text { and extensively } \\
\text { applied }\end{array}$ \\
\hline Dynamic logic & $\begin{array}{l}\text { Database up- } \\
\text { dates and } \\
\text { action logic }\end{array}$ & Ditto & $\begin{array}{l}\text { Possible ac- } \\
\text { tions }\end{array}$ & $\begin{array}{l}\text { Multimodal } \\
\text { logics are } \\
\text { on the rise. } \\
\text { Quantification } \\
\text { and context } \\
\text { becoming very } \\
\text { active }\end{array}$ \\
\hline \multirow[t]{3}{*}{$\begin{array}{l}\text { Types. Term } \\
\text { rewrite sys- } \\
\text { tems. Abstract } \\
\text { interpretation }\end{array}$} & $\begin{array}{l}\text { Abduction, rel- } \\
\text { evance }\end{array}$ & Ditto & $\begin{array}{l}\text { Agent's } \\
\text { implementation } \\
\text { rely on } \\
\text { proof theory. }\end{array}$ & \\
\hline & $\begin{array}{l}\text { Inferential } \\
\text { databases. } \\
\text { Non-monotonic } \\
\text { coding of } \\
\text { databases }\end{array}$ & Ditto & $\begin{array}{lr}\text { Agent's rea- } \\
\text { soning } \\
\text { non-monotonic }\end{array}$ & $\begin{array}{l}\text { A major area } \\
\text { now. Impor- } \\
\text { tant for formal- } \\
\text { ising practical } \\
\text { reasoning }\end{array}$ \\
\hline & $\begin{array}{l}\text { Fuzzy and } \\
\text { probabilistic } \\
\text { data }\end{array}$ & Ditto & $\begin{array}{l}\text { Connection } \\
\text { with decision } \\
\text { theory }\end{array}$ & $\begin{array}{l}\text { Major area } \\
\text { now }\end{array}$ \\
\hline $\begin{array}{l}\text { Semantics for } \\
\text { programming } \\
\text { languages. } \\
\text { Martin-Löf } \\
\text { theories }\end{array}$ & $\begin{array}{l}\text { Database } \\
\text { transactions. } \\
\text { Inductive } \\
\text { learning }\end{array}$ & Ditto & $\begin{array}{ll}\text { Agents } & \text { con- } \\
\text { structive } & \\
\text { reasoning } & \end{array}$ & $\begin{array}{l}\text { Still a major } \\
\text { central alterna- } \\
\text { tive to classical } \\
\text { logic }\end{array}$ \\
\hline $\begin{array}{l}\text { Semantics for } \\
\text { programming } \\
\text { languages. } \\
\text { Abstract in- } \\
\text { terpretation. } \\
\text { Domain recur- } \\
\text { sion theory. }\end{array}$ & & Ditto & & $\begin{array}{l}\text { More central } \\
\text { than ever! }\end{array}$ \\
\hline
\end{tabular}




\begin{tabular}{|c|c|c|c|c|}
\hline $\begin{array}{l}\text { Classical logic. } \\
\text { Classical frag- } \\
\text { ments }\end{array}$ & $\begin{array}{lr}\text { Basic } & \text { back- } \\
\text { ground } & \text { lan- } \\
\text { guage } & \end{array}$ & $\begin{array}{l}\text { Program syn- } \\
\text { thesis }\end{array}$ & A basic tool & \\
\hline $\begin{array}{l}\text { Labelled } \\
\text { deductive } \\
\text { systems }\end{array}$ & $\begin{array}{l}\text { Extremely use- } \\
\text { ful in modelling }\end{array}$ & & $\begin{array}{l}\text { A unifying } \\
\text { framework. } \\
\text { Context } \\
\text { theory. }\end{array}$ & $\begin{array}{l}\text { Annotated } \\
\text { logic programs }\end{array}$ \\
\hline $\begin{array}{l}\text { Resource and } \\
\text { substructural } \\
\text { logics }\end{array}$ & $\begin{array}{l}\text { Lambek calcu- } \\
\text { lus }\end{array}$ & & $\begin{array}{l}\text { Truth } \\
\text { maintenance } \\
\text { systems }\end{array}$ & \\
\hline $\begin{array}{l}\text { Fibring and } \\
\text { combining } \\
\text { logics }\end{array}$ & $\begin{array}{l}\text { Dynamic syn- } \\
\operatorname{tax}\end{array}$ & $\begin{array}{l}\text { Modules. } \\
\text { Combining } \\
\text { languages }\end{array}$ & $\begin{array}{l}\text { Logics of space } \\
\text { and time }\end{array}$ & $\begin{array}{l}\text { Combining fea- } \\
\text { tures }\end{array}$ \\
\hline $\begin{array}{l}\text { Fallacy } \\
\text { theory }\end{array}$ & & & & \\
\hline $\begin{array}{l}\text { Logical } \\
\text { Dynamics }\end{array}$ & $\begin{array}{l}\text { Widely applied } \\
\text { here }\end{array}$ & & & \\
\hline $\begin{array}{l}\text { Argumentation } \\
\text { theory games }\end{array}$ & & $\begin{array}{l}\text { Game seman- } \\
\text { tics gaining } \\
\text { ground }\end{array}$ & & \\
\hline $\begin{array}{l}\text { Object level/ } \\
\text { metalevel }\end{array}$ & & & $\begin{array}{l}\text { Extensively } \\
\text { used in AI }\end{array}$ & \\
\hline $\begin{array}{l}\text { Mechanisms: } \\
\text { Abduction, } \\
\text { default } \\
\text { relevance }\end{array}$ & & & ditto & \\
\hline $\begin{array}{l}\text { Connection } \\
\text { with neural } \\
\text { nets }\end{array}$ & & & & \\
\hline $\begin{array}{l}\text { Time-action- } \\
\text { revision mod- } \\
\text { els }\end{array}$ & & & ditto & \\
\hline
\end{tabular}




\begin{tabular}{|c|c|c|c|c|}
\hline & $\begin{array}{l}\text { Relational } \\
\text { databases }\end{array}$ & $\begin{array}{l}\text { Logical com- } \\
\text { plexity classes }\end{array}$ & $\begin{array}{l}\text { The workhorse } \\
\text { of logic }\end{array}$ & $\begin{array}{l}\text { The study of } \\
\text { fragments is } \\
\text { very active and } \\
\text { promising. }\end{array}$ \\
\hline & $\begin{array}{l}\text { Labelling } \\
\text { allows for } \\
\text { context } \\
\text { and control. }\end{array}$ & & Essential tool. & $\begin{array}{l}\text { The new unify- } \\
\text { ing framework } \\
\text { for logics }\end{array}$ \\
\hline \multirow[t]{9}{*}{ Linear logic } & & & $\begin{array}{l}\text { Agents } \\
\text { have } \\
\text { limited } \\
\text { resources }\end{array}$ & \\
\hline & $\begin{array}{l}\text { Linked } \\
\text { databases. } \\
\text { Reactive } \\
\text { databases }\end{array}$ & & $\begin{array}{l}\text { Agents are } \\
\text { built up of } \\
\text { various fibred } \\
\text { mechanisms }\end{array}$ & $\begin{array}{l}\text { The notion of } \\
\text { self-fibring al- } \\
\text { lows for self- } \\
\text { reference }\end{array}$ \\
\hline & & & & $\begin{array}{l}\text { Fallacies are } \\
\text { really valid } \\
\text { modes of rea- } \\
\text { soning in the } \\
\text { right context. }\end{array}$ \\
\hline & & & $\begin{array}{l}\text { Potentially ap- } \\
\text { plicable }\end{array}$ & $\begin{array}{l}\text { A dynamic } \\
\text { view of logic }\end{array}$ \\
\hline & & & & $\begin{array}{l}\text { On the rise } \\
\text { in all areas of } \\
\text { applied logic. } \\
\text { Promises a } \\
\text { great future }\end{array}$ \\
\hline & & & $\begin{array}{l}\text { Important fea- } \\
\text { ture of agents }\end{array}$ & $\begin{array}{l}\text { Always central } \\
\text { in all areas }\end{array}$ \\
\hline & & & $\begin{array}{l}\text { Very important } \\
\text { for agents }\end{array}$ & $\begin{array}{l}\text { Becoming part } \\
\text { of the notion of } \\
\text { a logic }\end{array}$ \\
\hline & & & & $\begin{array}{l}\text { Of great im- } \\
\text { portance to the } \\
\text { future. Just } \\
\text { starting }\end{array}$ \\
\hline & & & $\begin{array}{l}\text { A new theory } \\
\text { of logical agent }\end{array}$ & $\begin{array}{l}\text { A new kind of } \\
\text { model }\end{array}$ \\
\hline
\end{tabular}

